\title{
CONCEPT AND PERIODISATION OF FRAUD MODELS: THEORETICAL REVIEW
}

\author{
Maria Vassiljev \\ Tallinn University of Technology \\ Lehte Alver \\ Tallinn University of Technology
}

\begin{abstract}
The issue of fraud is topical in every country and for every type of organization, regardless of the continent or the part of the world. Getting involved into a fraud scandal, the future reputation becomes doubtful from the potential investors' and customers' point of view. Many authors have discussed the nature of fraud and have conducted research on the topic. The fraud triangle is the most popular model of explaining the nature of fraud. Regardless of the clearness of the elements of the fraud triangle, researchers have defined its components differently. In the typology of fraud, the components included are also different and the paper presents several examples. Different authors have created new types of the fraud models. For periodization the authors composed the timeline from 1950 to 2016. The chronology and concept of 15 fraud models from 1984 to 2016 are given. An extensive review of the concept of fraud and financial statement fraud is completed in the paper. Comparing to previous studies, the paper suggests a more complete review of the models describing the nature of fraud. One possible implication of this study is a justified need to research the topic in the future.
\end{abstract}

Keywords: white-collar crime, fraud, financial statement fraud, fraud models

JEL code: M410, M420

\section{Introduction}

Financial reporting fraud is only a spall of a huge growing ball named "fraud". It is a justified plea that fraud as a phenomenon is as old as humankind. In the ancient times people learned to cheat each other with a purpose of staying alive. In the process of growing up and developing the humankind has assessed new values, where a significant role is played by money and wealth. Fraud has replaced cheating. As the volumes and scale of frauds became notable, the researchers began to explore the nature of fraud in order to detect and to prevent the phenomenon. Rossouw (2000, p. 885) has pointed out that "fraud is a worldwide phenomenon that ruins the profitability, reputability, and legitimacy of organizations wherever it occurs". Fraud is far from benign. The fraudsters take advantage of technology and fraud becomes more sophisticated. "It can no longer be characterized solely as employee theft for personal benefit. It is international" (Silverstone and Sheetz, 2007, p. 14). The issue of fraud is topical in every country, regardless of the continent or the part of the world. Both private and public organizations have experienced being victims of fraudulent behaviour (Ruankaew, 2016). "Various corporate, social and political scandals, fraud and corruption in government, and the fraudulent practices in politics, financial institutions, corporations, nongovernmental organizations and religious institutions impact the legitimacy of such institutions" (Cooper, Dacin and Palmer, 2013, p. 440).

Why is fraud such an unknown and sometimes too complicated phenomenon? Fraud is an implicit kind of offense, and even if it happens it stays mostly unknown. Many authors have discussed about the nature of fraud and have researched the topic thoroughly. Most authors analyse fraud from the perspective of preventing crime. One of the well-known scientific 
methods is to use modelling. There are different fraud models composed during last decades, explaining all components of fraud. The authors of the current paper are of the opinion that the researchers have not paid any attention to the interconnection between the fraud concept and the existing fraud models. According to the research gap, the aim of the current paper is to define the system of fraud as a phenomenon through answering the following questions what is the nature of fraud? What are the types of fraud? What kind of models explain the phenomenon of fraud? In comparison with previous studies the paper gives a more complete review of the models, describing the nature of fraud.

\section{Concept of white-collar crime}

Edwin H. Sutherland was the first researcher, who dealt with fraud as a crime. He used a term of "white-collar crime" in his description of the nature of fraud. In 1940 he presented his views as an argument of white-collar criminality regarding theories of criminal behaviour (Sutherland, 1940). He found that white-collar criminality is a real criminality, which differs from lower class criminality (Dorminey, Fleming, Kranacher and Riley, 2012, p. 557).

Susan P. Shapiro (1980) concentrated on the content of white-collar crime. She has used Herbert Edelhertz's classification of the offence, given in 1970. According to the classification there are four categories of white-collar crime: (1) "person-crimes" enacted by individuals on an ad hoc basis for personal gain in a non-business context; (2) "abuses of trust" enacted by persons in the course of their occupations in violation of their duty of loyalty to employer; (3) "business crimes" incidental to furtherance of business operations and (4) "con games" or white-collar crimes which are the central activity of business (i.e. Ponzi schemes) (Shapiro, 1980, p. 12).

White-collar crime is a kind of a latent crime. "White-collar crime is one of the least understood and arguably most consequential of all crime types" (Simpson, 2013, p. 309). Researchers agree with Edwin H. Sutherland that white-collar crime is a crime but they disagree with the opinion that white-collar crime is somehow a softer kind of crime that should be judged differently. In their opinion it is important to understand that as white-collar crimes have changed over the years, so have the white-collar criminals. The main misconception of the white-collar crime is that these crimes are non-violent and are committed by those who are non-violent in nature. It is a kind of dangerous misconception as it implies that all white-collar crimes are not harmful or cause violence.

\section{Definition of fraud}

At first the researchers used the term "white-collar crime". Later the researchers started prevalently to use the term "fraud" and it can be noted that both terms are accepted as synonyms. Nevertheless, some authors have a different opinion concerning the relationship between fraud and white-collar crime. Silverstone and Sheetz (2007) state that white-collar crime should be viewed as a subclass of fraud because fraud includes schemes, art forgery, falsified scientific research data, lying and so on, while white-collar crime is committed by individuals embezzling, manipulating accounts, taking bribes, and so on at their place of business. Different authors use some other synonyms of fraud. Occasionally "fraud" and "misconduct" are used interchangeably, more or less as synonyms.

There are a lot of definitions of fraud. First, it is necessary to explain the possible origin of the word "fraud". Fraud originated from the Latin word, 'fraus', which means harm, wrongdoing, and deceit (Silverstone et al., 2007, p. 3). The same authors define fraud as an activity that takes place in a social setting and has severe consequences for the economy, corporations, and individuals. For example, Özkul and Pamukḉu (2012, p. 19) used a definition of fraud 
explained by The Institute of Turkish History: "a deceptive trick, scam, game, artifice, cabal which is committed to cheat, mislead someone" and "contributing something useless to something in order to gain advantage". Ramamoorti and Olsen (2007, p. 53) included the human factor into the definition. "Fraud is a human endeavour, involving deception, purposeful intent, intensity of desire, risk of apprehension, violation of trust, rationalization, etc." Ramamoorti, Morrison and Koletar (2009, p.11) used a short but weighty in the content definition "Fraud is deception, fooling another's perception."

There are some other definitions of fraud according to the matter and circumstances. For example, "fraud within organizations can be defined as intentional deception by concealing or misrepresenting information that harms the financial interest of another person(s) and benefits the financial interests of the perpetrator" (Rossouw, 2000, p. 887). The current paper concentrates on the financial fraud, as one of the most intricate types of fraud.

\section{Typology of the financial fraud}

As fraud has a very diverse nature, there is a need for the typology of the phenomenon. As Ramamoorti et al. have stated in 2009 "frauds take on a dizzying variety of forms, from the corporate frauds to the welfare recipient selling his or her food stamps at a discount to gain cash to buy alcohol or drugs, to the scam artist calling old people at home to sell them overpriced or worthless goods" (Ramamoorti et al., 2009, p.4).

Different authors have included different components into the financial fraud's typology. For illustration the authors are using the following:

1. Silverstone and Sheetz (2007) presented the following types of financial fraud, based on the company's activities: a) sales and collections; b) purchases and payments; c) payroll and personnel; d) inventory and warehousing; e) capital acquisition and repayment;

2. One of the newest approaches is provided by Patricia Z. Galletta in 2015 (p. 54-55):

a. Employee embezzlement: stealing the funds or property of an employer, company, or government or misappropriating money or assets held in trust, and it includes bribes or kickbacks;

b. Ponzi scheme: this is a fraud disguised as an investment opportunity, in which initial investors are paid out of funds raised from later investors. This would result in the later investors losing all of their invested funds;

c. Pump-and-dump schemes. These begin with individuals trying to raise the stock market price with false or misleading statements about a target company ("pump"). When the market price reaches a certain level, the fraudsters sell their own holdings ("dump") for a profit;

d. Vendor fraud. This type of fraud includes overcharging, selling inferior goods, price fixing, non-shipment or partial shipment after payment is received, and potential kickbacks and bribes or shell companies;

e. Consumer fraud. This is an intentional act, statement, or practice that harms consumers, such as credit card schemes, false advertising, overcharging, or concealing a fee.

f.Miscellaneous fraud. Some examples of miscellaneous fraud include altering birth records, false sweepstakes, and fraudulent work-at-home opportunities.

\section{Financial reporting fraud}

The financial reporting fraud is researched by many authors. Financial reporting is the only tool providing information to their users with the necessary financial information concerning the firm's activities. This is the reason why financial reporting frauds are a serious threat for 
the investor's confidence in the financial information (Vlad, Tulvinchi and Chirita, 2011, p. 264). "The high incidence of fraud is a serious concern for investors as fraudulent financial reports can have a substantial negative impact on a company's existence as well as market value" (Hogan, Rezaee, Riley and Velury, 2008, p. 232).

There are several definitions of the financial statement fraud. For example, the term fraudulent financial reporting, also known as financial statement fraud or management fraud, refers to fraud committed when the financial reports contain misrepresentation of material facts or such material facts have not been adequately disclosed in such reports (Goel and Gangolly, 2011). Another much broader definition is worth mentioning: "Fraud in financial reporting is based on conscious intent of the perpetrator (directors, auditors, employees, etc.) to wrongfully present the reality" (Vlad et al., 2011, p. 264). Omar and Din (2010, p. 607) provided their vision of financial statement fraud, according to which "Financial statement fraud is a situation where the disclosure of information as portrayed in the financial statements is being deliberately or intentionally omitted or distorted by the preparers."

The scientific literature divided financial statement fraud into three main parts: assumptions of the financial reporting fraud, types of misrepresentation of financial statements and the consequences of financial statement frauds. In the context of the paper, assumptions of the financial reporting fraud are taken into consideration. They are observed through different fraud models.

\section{The Fraud Triangle}

The criminologist Donald Cressey was the first researcher who determined the reasons for the commitment of fraud. In his paper "The Criminal Violation of Financial Trust" he defined three elements that must be present for occupational fraud (Cressey, 1950):

1. a pressure or incentive;

2. an opportunity;

3. a rationalization.

Cressey's three elements are also called as "fraud triangle". The fraud triangle is the most popular model of explaining the nature of fraud. Regardless of the clearness of the elements of fraud triangle, researchers have defined differently its components and have presented different examples for each (Kassem and Higson, 2012). Nevertheless, the fraud triangle is included in the professional auditing standards around the world including the international standards of auditing - ISA 240.

Researchers have analysed the fraud triangle from different aspects, and more and more of them claim that the fraud triangle is not an exhaustive model. There are several reasons for that statement:

1. The majority of authors have claimed that financial markets and white-collar schemes have changed drastically since Sutherland described his understandings in 1940. In this context, the fraud triangle does not explain adequately the changed situation for the whitecollar criminal types of acts (Dorminey et al., 2012).

2. Buchholz (2012) showed in his paper that there are some potential weaknesses in the fraud triangle, the two most important being: a) the fraud triangle used against the auditor. In that the auditors themselves become an opportunity; b) the concept of attitudes/rationalization should be eliminated because in some cases criminals come up with excuses but they know what they are doing and why they are doing it.

3. Kassem and Higson (2012) mentioned in their paper that the model alone is an inadequate tool for deterring, preventing, and detecting fraud. In the opponents' opinion, 
two sides of the fraud triangle (pressure and rationalization) cannot be observed, and some important factors, like fraudsters' capabilities are ignored.

4. One more possible argument to review the fraud triangle model is that fast development of technology creates new types of fraud risk (Gonzalez, 2012).

5. Huber (2016) is in position that fraud triangle is not more qualified as a theory to explain the nature of fraud: "The fraud triangle has been the subject of several criticisms such as emphasizing individual factors that contribute to fraud while ignoring social and organizational factors... However, the simple fact is, there is not now, and never has been, a fraud triangle other than only the name. Fraud does not, and cannot, map to the fraud triangle and thus the term "fraud triangle" is misleading" (Huber, 2016, p. 4).

In 2008, Ramamoorti stated that "it is also important to look at the other fraud triangle that focuses on the act, the concealment, and the conversion (that benefits the white collar criminal directly or indirectly)" (Ramamoorti, 2008, p. 530). Dorminey et al. (2012) emphasized in their paper the necessity "to look behind the triangle". In their opinion "to enhance our understanding of the fraudster's motivations and improve the anti-fraud community's ability to prevent, deter, detect, investigate, and remediate fraud, researchers and practitioners have offered insights beyond the Fraud Triangle" (Dorminey, et al., 2012, p. 555). These additional models seek to identify supplementary psychological or sociological characteristics (personality and behavioural) to describe those tendings toward fraud (Dorminey et al., 2012). Other authors also justify the necessity of the fraud triangle's modification. The following section gives a full overview about additional fraud models.

\section{Additional fraud models}

Different authors have attempted to remove the previously named shortcomings and created new types of the fraud triangles. The timeline presented in Figure 1, composed by the authors, demonstrates how fraud models have changed over time. The chronology and concept of 15 fraud models is given in Table 1.

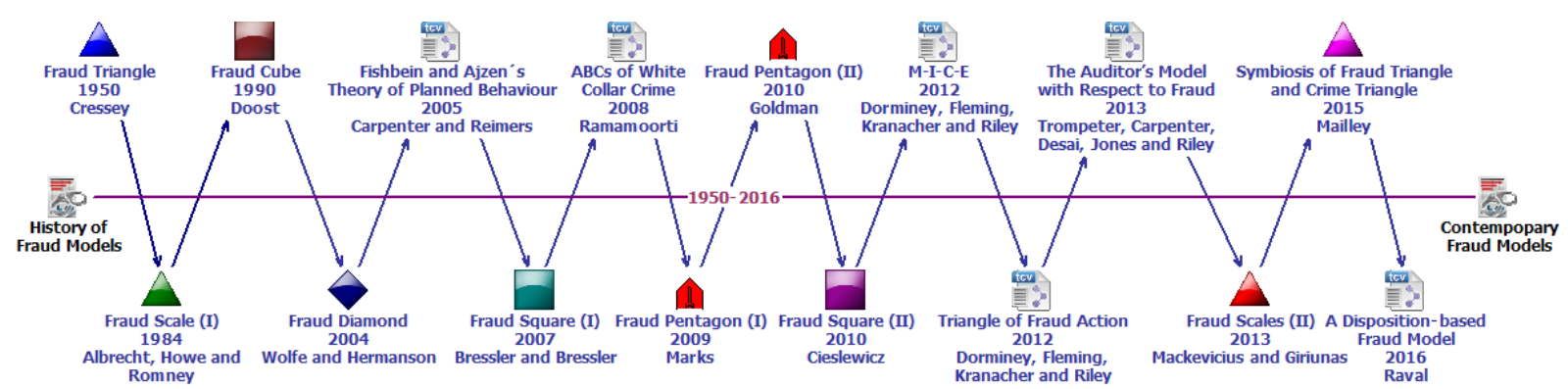

Figure 1. The timeline of the fraud models from 1950 to 2016 
Table 1. Chronology and concept of fraud models

\begin{tabular}{|c|c|c|}
\hline No. & Model, Author, (Year) & Concept of the model in comparison with the fraud triangle \\
\hline 1 & $\begin{array}{l}\text { Fraud Scale (I) } \\
\text { Albrecht, Howe and Romney } \\
\text { (1984) }\end{array}$ & $\begin{array}{l}\text { Albrecht, Howe and Romney (1984) developed a "fraud scale" relying on two components of } \\
\text { the fraud triangle, pressure and opportunity, but replacing rationalisation with personal integrity } \\
\text { (Free, 2015, p.183) }\end{array}$ \\
\hline 2 & $\begin{array}{l}\text { Fraud Cube } \\
\text { Doost (1990) }\end{array}$ & $\begin{array}{l}\text { "Underlying this concept is the ideology that there are three dimensions encompassing } \\
\text { computer crime - relationship, expertise and motivation" (Tran, 1992, p. 21) }\end{array}$ \\
\hline 3 & $\begin{array}{l}\text { Fraud Diamond } \\
\text { Wolfe and Hermanson } \\
\text { (2004) }\end{array}$ & $\begin{array}{l}\text { In addition to incentive, opportunity, and rationalization, the authors proposed the forth side, } \\
\text { which changed the triangle into diamond. Four-sided "fraud diamond" also considers an } \\
\text { individual's capability: personal traits and abilities that play a major role in whether fraud may } \\
\text { actually occur even with the presence of the other three elements (Wolfe \& Hermanson, 2004). } \\
\text { "Based on the fraud diamond theory, the person also must have the capability to recognize the } \\
\text { open doorway as an opportunity and to take advantage of it" (Ruankaew, 2016, p. 476) }\end{array}$ \\
\hline 4 & $\begin{array}{l}\text { Fishbein and Ajzen's Theory } \\
\text { of Planned Behaviour (TPB) } \\
\text { Carpenter and Reimers } \\
(2005)\end{array}$ & $\begin{array}{l}\text { "The four dimensions of the TPB are: attitude (toward fraud), subjective norms, perceived } \\
\text { behavioural control and moral obligation. The TPB is not a fraud model as such; however, its } \\
\text { purpose is to explain any planned, or intentioned, action. Since fraudulent acts are essentially } \\
\text { planned behaviours contingent upon the will of the actor, the TPB framework is relevant in } \\
\text { financial fraud research (Raval, 2016, p. 2). }\end{array}$ \\
\hline 5 & $\begin{array}{l}\text { Fraud Square }(\mathbf{I}) \\
\text { Bressler and Bressler } \\
(2007)\end{array}$ & $\begin{array}{l}\text { Four elements of the fraud square proposed: incentive, opportunity, capability, and realization } \\
\text { (Mackevicius \& Giriunas, 2013, p.152). }\end{array}$ \\
\hline 6 & $\begin{array}{l}\text { ABCs of White Collar Crime } \\
\text { Ramamoorti (2008) }\end{array}$ & $\begin{array}{l}\text { ABC: A - the Bad Apple: individual personality characteristics of those that commit fraud; B - } \\
\text { the Bad Bushel: group dynamics of collusive behaviour; C - the Bad Crop: the larger } \\
\text { cultural/societal factors that enhance or permit fraud. }\end{array}$ \\
\hline 7 & $\begin{array}{l}\text { Fraud Pentagon (I) } \\
\text { Marks (2009) }\end{array}$ & $\begin{array}{l}\text { Fraud pentagon consists of five elements: pressure, opportunity, rationalization, competence, } \\
\text { and arrogance, where "competence expands on Cressey's element of opportunity to include an } \\
\text { individual's ability to override internal controls and social controls to his or her advantage. } \\
\text { Arrogance or lack of conscience is an attitude of superiority and entitlement or greed on the } \\
\text { part of a person who believes that corporate policies and procedures simply do not personally } \\
\text { apply" (Marks, 2009, p. 3). }\end{array}$ \\
\hline 8 & $\begin{array}{l}\text { Fraud Square (II) } \\
\text { Cieslewicz (2010) }\end{array}$ & The notion of societal influences added to the fraud triangle (Free, 2015, p.182). \\
\hline 9 & $\begin{array}{l}\text { Fraud Pentagon (II) } \\
\text { Goldman (2010) }\end{array}$ & $\begin{array}{l}\text { Goldman adds the dimensions of personal greed and employee disenfranchisement (Free, 2015, } \\
\text { p.182). }\end{array}$ \\
\hline 10 & $\begin{array}{l}\text { Triangle of Fraud Action } \\
\text { Dorminey, Fleming, Kranacher } \\
\text { and Riley (2012) }\end{array}$ & $\begin{array}{l}\text { While the Fraud Triangle identifies the conditions under which fraud may occur, the Triangle of } \\
\text { Fraud Action describes the actions an individual must perform to perpetrate the fraud. The three } \\
\text { components of the Triangle of Fraud Action are the act, concealment, and conversion. "The act } \\
\text { represents the execution and methodology of the fraud, such as embezzlement, check kiting, or } \\
\text { material fraudulent financial reporting. Concealment represents hiding the fraud act; examples } \\
\text { of concealment include creating false journal entries, falsifying bank reconciliations, or } \\
\text { destroying files. Conversion is the process of turning the ill-gotten gains into something usable } \\
\text { by the perpetrator in a way that appears to be legitimate; examples include laundered money, } \\
\text { cars, or homes. (Dorminey et al., 2012, p. 559). }\end{array}$ \\
\hline 11 & $\begin{array}{l}\text { M-I-C-E } \\
\text { Dorminey, Fleming, Kranacher } \\
\text { and Riley } \\
\text { (2012) }\end{array}$ & $\begin{array}{l}\text { 'M' means 'money', 'I' - 'ideology', 'C' - 'coercion' and 'E' means 'ego' or 'entitlement'. M- } \\
\text { I-C-E modifies the pressure side of the Fraud Triangle, as it provides an expanded set of } \\
\text { motivations beyond a non-shareable financial pressure (Dorminey et al., 2012). }\end{array}$ \\
\hline 12 & $\begin{array}{l}\text { Fraud Scales (II) } \\
\text { Mackevicius and Giriunas } \\
(2013)\end{array}$ & $\begin{array}{l}\text { "The elements of the fraud scales are the following: motives, conditions, capabilities and } \\
\text { fulfilment. The first element of the fraud scales is the motive. It determines whether an } \\
\text { employee tends to behave unfairly and why. The second element of the fraud scales is the study } \\
\text { of the conditions that increase their risk. The third element is the possibilities, which are treated } \\
\text { as an option granted to an employee who is hoping to commit a fraud. The fourth element is } \\
\text { realization, which is seen as a means by which employees justify unfair behaviour" } \\
\text { (Mackevicius and Giriunas, 2013, p. 159-160). }\end{array}$ \\
\hline 13 & $\begin{array}{l}\text { The Auditor's Model with } \\
\text { Respect to Fraud } \\
\text { Trompeter, Carpenter, Desai, } \\
\text { Jones and Riley } \\
\text { (2013) }\end{array}$ & $\begin{array}{l}\text { Is a kind of adopted model of fraud triangle as a pre-fraud state of nature in combination with } \\
\text { post-fraud state, which focuses on the specific elements of fraud: the act, the effort to conceal } \\
\text { the act and an identification of the benefits that accrue to the fraudster (Trompeter, Carpenter, } \\
\text { Desai, Jones, and Riley, 2013, p. 290). }\end{array}$ \\
\hline 14 & $\begin{array}{l}\text { Symbiosis of Fraud Triangle } \\
\text { and Crime Triangle } \\
\text { Mailley (2015) }\end{array}$ & $\begin{array}{l}\text { The Crime Triangle is introduced as a complement to the universally accepted Fraud Triangle. } \\
\text { The Crime Triangle's macro view of a fraud event expands the Fraud Triangle's perpetrator- } \\
\text { centric (micro) focus to provide a comprehensive perspective of a fraud event (Mailley, 2015, } \\
\text { p. 56). }\end{array}$ \\
\hline 15 & $\begin{array}{l}\text { A Disposition-based Fraud } \\
\text { Model } \\
\text { Raval (2016) }\end{array}$ & $\begin{array}{l}\text { "A complete model of human behaviour should include the two interacting elements: organism } \\
\text { (agent) and environment (context)... This model frames financial fraud as an act of } \\
\text { indulgence: People commit fraud by indulging in a moral temptation, leading to an intentional } \\
\text { act... Thus, the Disposition-based Fraud Model is essentially an interaction between (a) } \\
\text { circumstances represented by stimuli that make up the moral temptation on hand, and (b) the } \\
\text { actor's character (disposition)" (Raval, 2016, p. 4) }\end{array}$ \\
\hline
\end{tabular}




\section{Conclusion}

Fraud has a very diverse nature and that is why the definitions vary a lot. This is one of the reasons why there are a lot of different opinions. For the same reason different fraud models have been built up. The authors of the current paper systemized the prevailing majority of fraud models, gave the chronology and a short description of each of them. Summing up the literature, the authors have to conclude that it is important that the topic should receive more attention, and researchers all over the world want to emphasize the importance of the problem, to solve it and prevent new crimes.

\section{Literature}

Buchholz, A. K. (2012). SAS 99: Deconstructing the Fraud Triangle and Some Classroom Suggestions. Journal of Leadership, Accountability and Ethics, no. 9 (2), pp. 109-118.

Cooper, D. J., Dacin, T., Palmer, D. A. (2013). Fraud in accounting, organizations and society: Extending the boundaries of research. Accounting, Organizations and Society, no. 38, pp. 440-457.

http://doi.org/10.1016/j.aos.2013.11.001

Cressey, D. R. (1950). The criminal violation of financial trust. American Sociological Review, pp. 738-743

Dorminey, J., Fleming, A. S., Kranacher, M.-J., Riley, R. A. (2012). The Evolution of Fraud Theory. Issues in Accounting Education, no. 27 (2), pp. 555-579.

http://doi.org/10.2308/iace-50131

Free, C. (2015). Looking through the fraud triangle: a review and call for new directions. Meditari Accountancy Research, no. 23 (2), pp. 175-196.

http://doi.org/10.1108/MEDAR-02-2015-0009

Galletta, P. Z. (2015). A Basic Field Guide to Fraud. The CPA Journal, no. 549 (March), pp. 54-60.

Goel, S., Gangolly, J. (2011). Beyond the Numbers: Mining the Annual Reports for Hidden Cues Indicative of Financial Statement Fraud. Intelligent Systems in Accounting, Finance and Management, no. 176 (January), pp. 161-176.

http://doi.org/10.1002/isaf

Gonzalez, G. C. (2012). When is Computerized continuous Auditing Less Effective at Deterring Fraud? University of Pittsburgh.

Hogan, C. E., Rezaee, Z., Riley, R. A., Velury, U. K. (2008). Financial statement fraud: Insights from the academic literature. Auditing: A Journal of Practice \& Theory, no. 27 (2), pp. 231-252.

http://doi.org/10.2308/aud.2008.27.2.231

Huber, D. (2016). Forensic Accounting, the n-Dimensions of Financial Crime, and the End of the Fraud Triangle.

Retrieved from http://ssrn.com/abstract $=2423809$

Kassem, R., Higson, A. (2012). The New Fraud Triangle Model. Journal of Emerging Trends in Economics and Management Sciences, no. 3 (3), pp. 191-195.

Mackevičius, J., Giriunas, L. (2013). Transformational Research of The Fraud Triangle. Ekonomika, no. 92 (4), pp. 150-163. 
Mailley, G. M. J. (2015). A tale of two triangles: comparing the Fraud Triangle with criminology's Crime Triangle. Accounting Research Journal, 28 (1), pp. 45-58.

Marks, J. (2009). Playing Offense in a High-risk Environment. Crowe Horwath, New York.

Omar, N. B., Din, H. F. M. (2010). Fraud Diamond Risk Indicator: An Assessment of Its Importance and Usage. In 2010 International Conference of Science and Social Research, pp. 607-612.

Ramamoorti, B. S., Olsen, W. (2007). Fraud: the Human Factor. Financial Executive, no. 23 (6), pp. 53-55.

Ramamoorti, S., Morrison, D., Koletar, J. W. (2009). Bringing Freud to Fraud: Understanding the State-of-mind of the C-level Suite/white Collar Offender Through "A-B-C" Analysis. The Institute for Fraud Prevention, pp. 1-35.

Raval, V. (2016). A Disposition-based Fraud Model: Theoretical Integration and Research Agenda. Journal of Business Ethics, pp. 1-23.

Rossouw, G. J. (2000). Defining and understanding fraud: a south african case study. Business Ethics Quarterly, no. 10 (4), pp. 885-895.

Ruankaew, T. (2016). Beyond the Fraud Diamond. International Journal of Bussiness Management and Economic Research, no. 7 (1), pp. 474-476.

Shapiro, S. P. (1980). Thinking About White Collar Crime: Matters of Conceptualization and Research. Washington, DC: US Department of Justice, National Institute of Justice.

Silverstone, H., Sheetz, M. (2007). Forensic Accounting and Fraud Investigation for NonExperts. Second ed. Hoboken, New Jersey: John Wiley \& Sons.

Simpson, S. S. (2013). White-Collar Crime: A Review of Recent Developments and Promising Directions for Future Research. Annual Review of Sociology, 39, pp. 309-331. http://doi.org/10.1146/annurev-soc-071811-145546

Sutherland, E. H. (1940). White-collar criminality. American Sociological Review no. 5 (1), pp. $1-12$

Tran, T. N. (1992). Fraud - The Auditor's Dilemma: an honors thesis (HONRS 499).

Trompeter, G. M., Carpenter, T. D., Desai, N., Jones, K. L., Riley, R. A. J. (2013). A Synthesis of Fraud-Related Research. A Journal of Practice \& Theory, no. 32 (November 2012), pp. 287-321.

http://doi.org/10.2308/ajpt-50360

Vlad, M., Tulvinchi, M., Chirita, I. (2011). The consequences of fraudulent financial reporting. The Annals of The "Ştefan Cel Mare" University of Suceava. Fascicle of The Faculty of Economics and Public Administration, no. 11 (1), pp. 264-268.

Wolfe, D. T., Hermanson, D. R. (2004). The Fraud Diamond: Considering the Four Elements of Fraud. CPA Journal, no. 74 (12), pp. 38-42.

http://doi.org/DOI:

Özkul, F. U., Pamukḉu, A. (2012). Fraud Detection and Forensic Accounting. In Emerging Fraud, pp. 19-42.

http://doi.org/10.1007/978-3-642-20826-3 